\title{
Knowing Through Making: The Role of the Artefact in Practise-Based Research
}

In this article the making and the products of making are seen as an essential part of research: they can be conceived both as answers to particular research questions and as artistic or designerly argumentation. As an object made by an artist-researcher, the artefact can also be seen as a method for collecting and preserving information and understanding.

However, the artefacts seem unable to pass on their knowledge, which is relevant for the research context. Thus the crucial task to be carried out is to give a voice to the artefact. This means interpreting the artefact. During the process of interpretation, furthermore, the artefact has to be placed into a suitable theoretical context. In this process the final products (the artefacts) can be seen as revealing their stories, i.e. the knowledge they embody.

\author{
Maarit Mäkelä \\ University of Art and Design Helsinki UIAH \\ maarit.makela@uiah.fi
}

\begin{abstract}
INTRODUCTION
This article investigates the ways in which art can be understood as a process of inquiry. The idea of knowledge gained through art and design practises has been a widelydiscussed issue in the field of art and design research. In this article, the making and the products of making are viewed as an essential part of research.
\end{abstract}

In the last two decades, design research has searched through various modes of attaining knowledge and in this way laid down foundations for the discipline. Coinciding with the emergence of the discipline, there has been an ongoing debate about the role of art and design practices in the field of academic research. In this discussion the product of making i.e. the artefact created in art and design practice - is conceived to have a central position in the research process. The artefact can be e.g. a painting, a photograph, a designed object, a composition or a dance performance. This way of relating oneself to the field of research has been labelled practise-based research, and the new approach has recently been applied, discussed and argued over in the broad field of art - including dance, theatre, music, fine arts, applied arts and design.

In this article I will take a closer look at the practise-based approach and the central questions it poses in the fields of visual arts and design. The key question here lies in combining art and design practices within research. The viewpoint adopted in this article approaches the question with a focus on practise. The central question framed by a focus on the product of making is: what is the role of the artefact in practise-based research?

Within the frame of practise-based approach, artefacts have been conceived both as answers to particular research questions and as argumentation on the topic concerned. What I suggest here is that an artefact can embody a greater range of roles: as an object made by an artist-researcher during the process of research, it can also be seen as a method of collecting and preserving information and understanding. Thus the process of making and its products are strongly connected with the source of knowledge. In this sense we are facing the idea of knowing through making. For artists and designers practitioners of the field - this idea is evident. It also seems to have an important role in the ideas expressed by a group of theoreticians who have been structuring the genealogies of knowledge for the field of design, and have thus created a foundation for the research carried out in the field.

In the following I will first sketch out previously expressed ideas concerning the "designerly ways of knowing”. Secondly, I will evoke an ongoing discussion in the field of practisebased research dealing with the idea of knowing through making, with particular focus on the role of the artefact in the process of producing knowledge. Thirdly, I will move from practise to theory and express a need for constructing an appropriate theoretical frame for examining the working process and its products more closely. Based on this 
argumentation I will, finally, extend my discussion to some of the central notions I came across while preparing my own practise-based research. This research was carried out in the field of ceramic art and was recently defended in the form of a doctoral dissertation.

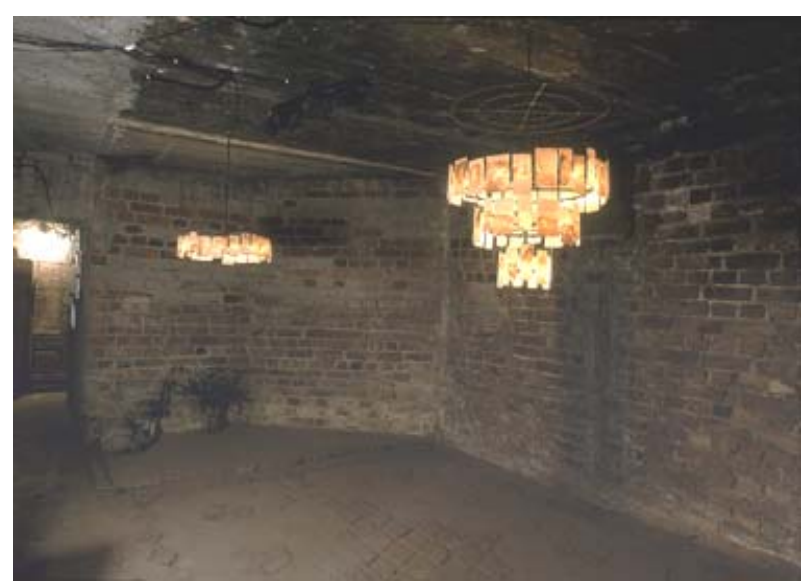

Figure 1: Exhibition Mirrorplay III (2000)

\section{DESIGNERLY WAYS OF KNOWING}

In the late 1960s Herbert Simon, a well known economist, proposed that "the science of design" could form a fundamental common ground for intellectual communication across the arts, sciences and technology. He suggested that the study of design could form an interdisciplinary field, open to everyone involved in the creative activity of making the artificial world. (Simon 1996, 111-114, 134-138; Cross 2001, 54.)

In the 1980s social scientist Donald Schön stressed the role of the practitioner, whose understanding and knowledge from a particular field corresponds to a perspective situated within the process of praxis. His thinking focused on the idea of a reflective practitioner. Schön proposed that research ought to be geared towards an understanding of the nature and origin of knowledge (i.e. epistemology) which is tied to the practice. (Schön 1995, viii.) More recently these ideas have been developed by Stephen Scrivener, who has moulded a practisebased research project - what he calls a creative-production project - on the basis of Shön's ideas (Scrivener 2000, Scrivener 2002a, Scrivener \& Chapman 2004.)

An understanding of the central role of the design practise has also been apparent in Nigel Cross's thinking. Cross has argued, that designers should concentrate on the underlying forms of knowledge particular to themselves. He pins this knowledge down to the practice of design which he labels "designerly" ways of knowing, thinking and acting. (Cross 1982 and 2001, 55.) Until the turn of the century he has been discussing the forms of knowledge particular to the awareness and abilities of a designer. He states that knowledge of design resides in people (i.e. designers), in the processes and in the products themselves (Cross 1982, 223-225 and 1999, 5-6). Part of this knowledge is inherent in the activity of designing. It can be gained by engaging in and reflecting on that very activity. Knowledge also resides in artefacts themselves; in the forms and materials. Some of this knowledge is also inherent in the process of manufacturing the artefacts, and it can be gained through making and reflecting upon the making of those artefacts. (Cross 2001, 54-55.)

Cross remarks that at the threshold of a new century, we are still constructing an appropriate paradigm for design research. In this context, he also speaks up in favour of his notion of “designerly ways of knowing”. (Cross 1999, 10.) Research in the context of art and design still seems to be a much-debated subject at the beginning of the $21^{\text {st }}$ century. The debate grows even stronger when the discussion touches upon the field of practise-based research - which can be regarded as one of the new ways of doing research that has been affected by the kind of accumulation of knowledge described above. Annoyance surfaces particularly when it is argued that the making of art and design comprises a research method and when the artefact is regarded as the aim of a research - the embodiment of new knowledge (Scrivener 2002a, 25).

In their editorial to the International journal of design sciences and technology (2002) David Durling, Ken Friedman and Paul Gutherson argued against practise-based research, starting with Cross's efforts to promote the category of making "research by design" in the early 1990s. They proclaimed that so far, this category has proven fruitless. In their view, the efforts of the past decade, aimed at producing valid examples of making "research by design", have failed. They also stated that until recently a practise-based $\mathrm{PhD}$ has been a concept unique to the UK. (Ibid. 10-11.)

Discussion on the possibility of conducting practise-based research projects has been going on in Finnish art universities since the beginning of the 1990s (Ryynänen 1999). The first practise-based dissertation in Finland in the field of visual art was completed in 1997 (Eskola 1997) and in the field of design in 2003 (Mäkelä 2003). Since some of the completed practisebased dissertations have been considered top quality in respect to the quality of their work, I claim that it is time to take this discourse and questions it poses seriously.

No doubt, in the UK the volume of people acting in the field of practise-based research has been the greatest. Some of these people have been engaged in developing the discourse for more than a decade. Many of the people involved are ready to argue that practise-based $\mathrm{PhD}$ research has become a recognised and valid form of research in art and design (e.g. Malin \& Gray $2000,406)$. During the last years, discussion on the possibility of carrying out research projects in the field of art and design in has spread ever more widely around Europe, for example in Sweden, Norway, Hungary, Belgium and Spain. However, the pioneer work has already been done in the UK and Finland.

\section{KNOWING THROUGH MAKING}

It has been argued that practice-based research is characterised by a focus on issues, concerns and interests that are explored and manifested through the production of creative artefacts. This implies that, as an object of experience, the creative product is as important as any knowledge embodied in it (Scrivener \& Chapman 2004, 2-3). The objects created (i.e. artefacts) translate messages between concrete objects and abstract requirements. In this way they facilitate the constructive, solution-focused thinking of the artist or the designer - in the same way other, for example verbal and numerical communication and thinking facilitates analytic, problem-focused thinking. (Cross 1982, 225.)

Also Scrivener has argued for comprehension of analogy between the material based thinking of the designer and other forms of thinking. He has suggested that the creative process should be recognised as complementary to mathematical, scientific and philosophical thinking. According to him, artefacts are not merely central in terms of outcome, they are also central to the very realisation of outcomes and hence must take central stage from the very outset of practice based research. In this context making functions as means of realising a thing which has to be perceived, recognized and conceived or understood. (Scrivener \& Chapman 2004, 8.)

Painter-researcher Peter Chapman links the creative process and the artefact created during the process together 
inseparably: it is the making of the artefact, even if intuitive, which determines the direction of the practice-based research process. Without the artefact there is just the assumptive theory, which is separated from the actual process of making. According to Chapman the understanding of both the process of making and the artefact should present a body of knowledge. (Scrivener \& Chapman 2004, 7.)

In conventional research, making is generally regarded consequent to thinking - at least in theory. Thus a series of an experiments, for example, are carried out in order to test a certain assumption i.e. to solve a problem or answer a question. In the field of practice-based research, praxis has a more essential role: making is conceived as the driving force behind the research and in certain modes of practice also the creator of ideas - such as, for example, painting. (Scrivener \& Chapman 2004,7 .) In this way invention comes before theory, i.e. the world of 'doing and making' is prior to understanding (Cross 1982, 225).

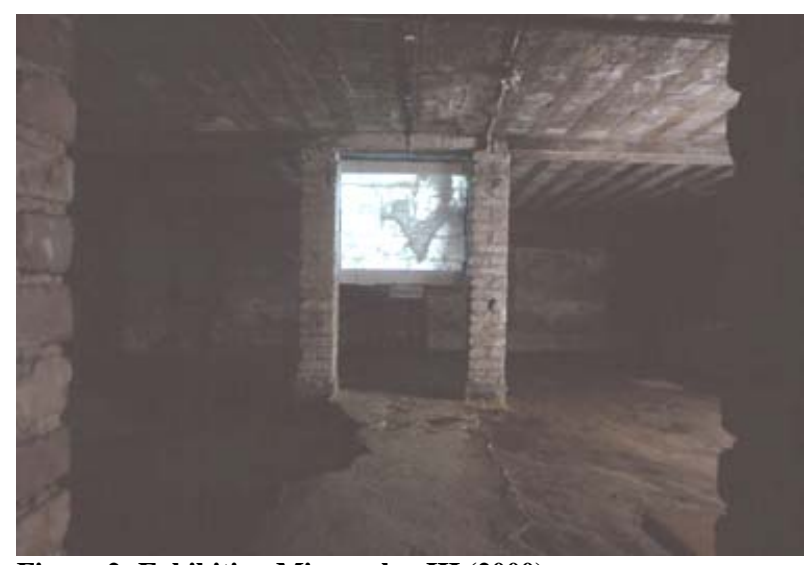

Figure 2: Exhibition Mirrorplay III (2000)

\section{Work of art as a bearer of knowledge}

Sculptor, PhD Michael Biggs states that the principal feature of practice-based research is the desire or need to create artefacts and to present them as part of the 'answer' to research questions posed at the outset. In this way, the practice-based enterprise is different from many other approaches, since it does not simply use objects as evidence, but attempts to present the objects created during the research process as arguments. This implies the notion that the artefact can embody the answer to the research question. Nevertheless, the products (artefacts) need to be interpreted rather than simply 'read' and this, according to Biggs, undermines their perception as putative answers. (Biggs 2002, 20.) I want to emphasise, that within the practise based enterprise it is (usually) the maker of the artefact i.e. the artist-researcher or designer-researcher him or herself who is interpreting the artefacts - though later on, after the process of making has been finished.

It has been argued that making brings into existence the artefact which is itself a form of knowledge (Scrivener 2002b, 1; Cross 1982, 225). Nevertheless, before revealing its knowledge, the artefact has to be interpreted (Scrivener 2002b, 8). Biggs supports the view that objects alone cannot embody knowledge: as such, there is no embodied knowledge in the artefact until it is interpreted. He emphasises that this action is staged in a certain context, and that the context affects the way the object is interpreted. (Biggs 2002, 23.)

In addition to emphasising the importance of context, Biggs also takes up the question of the role of words in the act of interpreting. In his view, it is a particular combination of artefacts and words that gives efficacy to the communication. When acting as bearers of meanings, neither artefacts nor words alone would be sufficient. He reverts to a definition of the research, made by a central funding body in the UK in the field of art and design, Arts and Humanities Research Board (AHRB). It proposes that what is required is a combination of artefact - for example painting or design - and a critical exegesis that illustrates how the artefact advances knowledge, understanding and insight. This implies that the artefact alone cannot be relied upon to communicate its information. (Biggs 2002, 23.)

When interpreting an artefact it, in a way, is set it into a certain context and through this action helped to find the words with which to reveal the knowledge it embodies. This action is the point whereupon the essence of knowledge will gain even more subjective features - after all, within the practise-based enterprise, it is the artist-researcher or designer-researcher who is interpreting the object in a context chosen by him or herself. This is also one of the distinctive features for research projects carried out in a practice-based context. As the knowledgeaccumulating process in such research projects is closely linked with the artist- or designer-researcher, the whole research setting strongly favours a subjective viewpoint.

\section{FROM PRACTISE TO THEORY}

There have been numerous opinions and suggestions concerning the essence of practise-based research and the direction this approach should develop into. Because the field of practise-based research, has up to the present, remained rather loosely demarcated, the single definition of such research made by the Arts and Humanities Research Board seems to be considered a cornerstone of the ongoing discussion. According to this definition, creative practise is not necessarily research, but creative practise that meets certain criteria can be regarded as research. The requirements are that there have to be explicit research questions, specific methods for answering the questions and a specific context in which the research is carried out (AHRB 2001, 7; Biggs 2002, 19; Scrivener 2002a, 33).

It has been argued, that there are questions and answers characteristic to practise-based research. Practise-led questions are questions that arise out of, and in a consequence to, practise. Some of these questions are pluralistic; i.e. they may be answered in a number of different ways. What seems to be the most important task during the process of practise-based research is show a clear connection between the question and the answer. The way to evaluate the function of the method used in a specific research project lies in this connection: a persuasive connection between the question and the answer proves the suitability of the method. (Biggs 2004, 12-13.)

As already mentioned, one feature of research in arts and design is that it is interpretational and pluralistic. There is no preference for one set of methods over another, since finding multiple solutions is regarded as an asset, not a weakness. There is a dynamic relation between research context, question, method and audience. Variation in any of these affects the appropriateness of the chosen method. This is the reason why a method is the last variable to be determined in the practisebased research process. This is also the reason why repeatedly applying a same method to advance of problems would be an invalid approach to research in art and design. (Biggs 2004, 1419.)

But what can be conceived as a method in this research context? Are we talking about the way in which we, as artists and designers, may use theoretical tools to be able to give a certain structure and find a suitable context for interpreting and handling our practice-based research projects? As stated earlier, in the field of conventional research the act of making (i.e. practice) is generally seen as a consequence of thinking 
(i.e. theory). Because practice-based research is characterised by focusing on issues, concerns and interests that are explored and manifested through the production of artefacts, we should take up this picking order as a fundamental issue: should we as artists and designers start to markedly build up our theorisation from the point of view that comes to us naturally, i.e. the perspective gained from praxis.

Instead of starting to build up our research on the basis of a specific set of methods, we should rely on praxis and make it a baseline for our research. What I am suggesting is that we should have a plan for our practice-based research projects, a plan with specific research question(s) and a context for carrying out the research. But instead of committing ourselves to using certain specific methods, we should be able to present a research frame, or rather the structure of a frame, in which it would be possible to carry out the practice-oriented journey.

As a practising artist I have a clear vision about the artistic working process and its meaning for the artist. I have no reason to oppose the idea that the process of making is a creative one for the artist or the designer, during which he or she may rearrange a number of ideas, beliefs and conceptions and thus advance her or his knowing, understanding and insight. But if we wish to transport the process of making into the context of research, we have to use the theoretical tools which enable us to grasp the creative process.

If we find a suitable way in which to combine practise with theory in a way which maintains practise as the driving force behind the research process as a whole, then the project has good premises for being successfully carried out. Or vice versa: if the creative process and its products are forced into a certain research frame too violently, we are in a danger of losing the core idea of such research, which is to act as a bridge into the creative process or, on the subjective level, to creativity itself. This remark and the danger it warns us of has been brought up in numerous discussions (e.g. Scrivener \& Chapman 2004, 5).

It is evident that a practise-based research can - and even should - have 'pure' artistic working periods during which we should not let the theory dilute the process. But if we are carrying out the practise in a research context, we have to be able to find - or as stated above, be capable and smart enough to construct by ourselves - an appropriate theoretical frame that enables us to examine this working period and its products more closely. In order to produce a more comprehensive view on the way such a task can be carried out, I will in the following offer a closer examination of my own research project - as a case study of successfully concluded practicebased research.

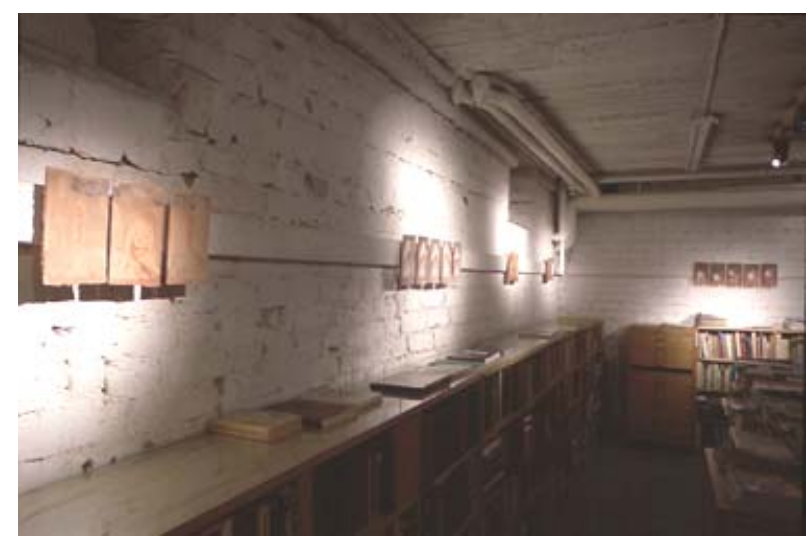

Figure 3: Exhibition Mirrorplay I (1996)

\section{CASE STUDY: MEMORIES ON CLAY}

I will now move on to view the key issues of practice-based research discussed above in the context of my own research. The presentation will be arranged in a way which illustrates its compatibility with the AHRB indicators for 'creative practise that can be regarded as research' (i.e. demand for explicit research questions, methods and context). This act or gesture is carried out in order to emphasise the point that even though operating within the novel field of research we - artist- or designer-researchers - need at least some kind of a frame in which, or against which, to build up our individual research projects.

\section{Methodological experiment: a dialogue between art practise and research}

The central methodological question of my doctoral dissertation "Memories on clay: representations of subjective creation process and gender" (Mäkelä 2003) comes from the emerging field of practise-based research: how can art practices interact with research in a way that will produce new knowledge and form new, creative ways of doing research. The artistic methods used in this research consist of exhibitions and the creative working processes related to them. The research was carried out in the form of three exhibitions of a series called "Mirrorplay" which was on display in the Laterna Magica gallery in Helsinki in 1996, 1997 and 2000.

The dialogue between the practise of art and research commenced after the artistic process, whereby the creative process and the artefacts created during it were set in a theoretical framework for interpretation. This action, as I see it, can be understood as one of the possible methods for making practise-based research. I regard this comprehension as one of the central results of my research: a tool that I have labelled the retrospective look (Mäkelä 2003, 23-28).

The written part of the doctoral dissertation, the thesis, can thus be considered a retrospective reading of the artistic working process and the art works created during the process. It consists of closer observations and interpretations of the working process and artefacts made during the process. A suitable context for interpreting the artefacts became fixed only when the artistic process was finished. In this case, I found mine in the field of post-feminist research, where sexual and gendered identities are conceived as products of a continuos process consisting of different strategies - such as art practices (e.g. Braidotti 1994, 163-165; de Lauretis 1986, 9).

\section{Research context: women's studies}

My research is a practical test of the way certain ideas concerning radical differences of gender and femininity as constituents of the second sex - as outlined by French theoreticians of gender difference, namely Luce Irigaray (e.g. 1974) - can be taken in consideration in artistic work that produces visual representations. During my research process I, as a practising artist, have therefore worked with a previouslyexisting collection of female images: either culturally embedded pictures of women, or photos taken from the family album of the artist. I have used the silk screen technique, and in the most recent work video technology as well (figure 4), in order to transfer the images on a ceramic surface and copy them on numerous clay tiles (figure 5). During this process the familiar prints radically change their shape, although the main themes still remain recognisable. These images bring their cultural meaning into the new ceramic pictures: Marilyn in her corporeality and Madonna in her saintliness.

In this particular research, a ceramic artist who has entered a creative artistic research process and a female artist acting in the field of contemporary art makes the question: how can 
"feminist" art, in this case ceramic art, change current representations of femininity? How is it possible to observe femininity or, rather, the different kinds of femininities, through ceramic materials? How do memories, autobiographies and narratives produce, change and transmit possible female identities? How does remembrance and autobiography construct narration in the process of making ceramic art?

My doctoral thesis consists of three main chapters. Each of them have their starting points in one of the three exhibitions in the "Mirrorplay" series or the main theme of that exhibition. The three main chapters of the dissertation are thus like reports on the exhibition spaces. They discuss three spatial totalities, each of which has a particular order; in these instances, an order produced and effected by a female artist. The chapters thematise the exhibitions in relation to the works displayed, the display rooms and the other exhibitions in the series. Although the main chapters can be regarded as individual units, they nevertheless form a thematic and chronological continuum - a narrative about the creative process which formed the basis of the dissertation. (Mäkelä 2003, 38.)

The first chapter of the study, titled "The reproduction and mimesis of Other(ness)" portrays the practise of art as a creative forum for action. Through a close reading of certain works displayed in the exhibition Mirrorplay I, I reflect upon the way in which by repetition and alteration of pre-existing images I end up rearranging and reinterpreting the things I experience and see. The chapter also includes quotes from written feedback received from female ceramic artists. Chapter two, titled "The female body engraved in clay", centres on corporeality as well as excreta which maintains a close symbolic connection with the body even though already physically excluded from it. In this chapter I portray the way in which I, as an artist, make use of the excreta from of my own body in my work. Bodily excreta are no longer part of the subject, yet neither are they objects completely separate from it - they are, rather, liminal and abject. The chapter includes excerpts from my working diary. In chapter three, "constructing female genealogy", I developed a gap-filled story onto an autobiographical space. I have used personal historical documents for creating this texture, such as family photographs as well as letters and diaries kept by my forbears. I have also collected memories and family histories through interviewing my relatives. (Mäkelä 2003, 38-39.)

\section{Clay images as recordings, analyses and commentaries of (female) experience}

Teresa de Lauretis, the central theoretician in the field of postfeminist research, approaches experience as a continuous process whereby subjectivity - the self - is formed. In her view, we should not discuss women "with experiences" but rather womanhood constructed by and through experiences. (de Lauretis 1984, 159.) My own womanhood is thus constructed through a process which includes my experiences both from the field of contemporary art and as a researcher contextualising that art. Such processional womanhood is also that which is written and engraved into my ceramic clay slates.

The exhibition series is centred around female figures transformed onto ceramic slates. Through the cultural meanings attached to these figures the pieces both question and reach beyond the female body, or rather the limits culturally constructed for it. This point of view emphasises the significance of the ceramic female images created in the research process: they become visual representations of womanhood created in a particular historical context out of the specific experiences of a female individual. In this research context art should thus be viewed as the primary forum of research. Artistic activity is not just a medium for gathering and producing knowledge, but also a method for analysing and commenting on the information thus produced. (Mäkelä 2003, 93.)

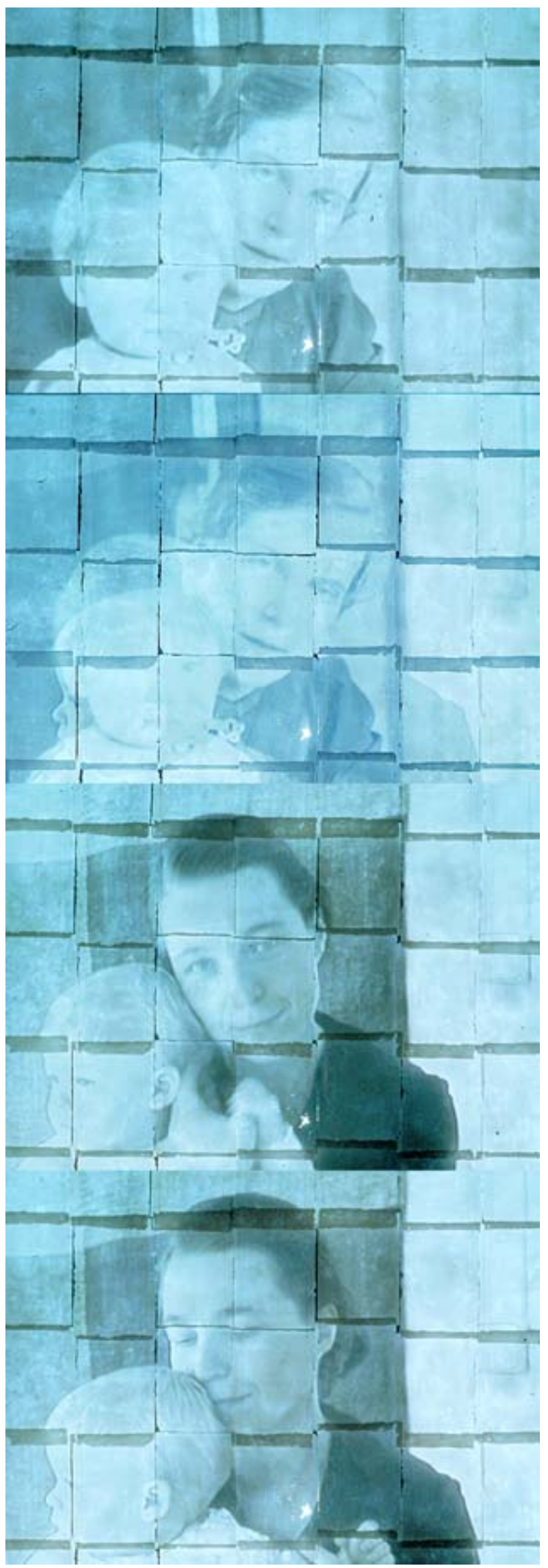

Figure 4: Four video cuts from porcelain screen. First cut is based on old family photo (1939), third and fourth cuts on contemporary video (2000) and second on both of them. 


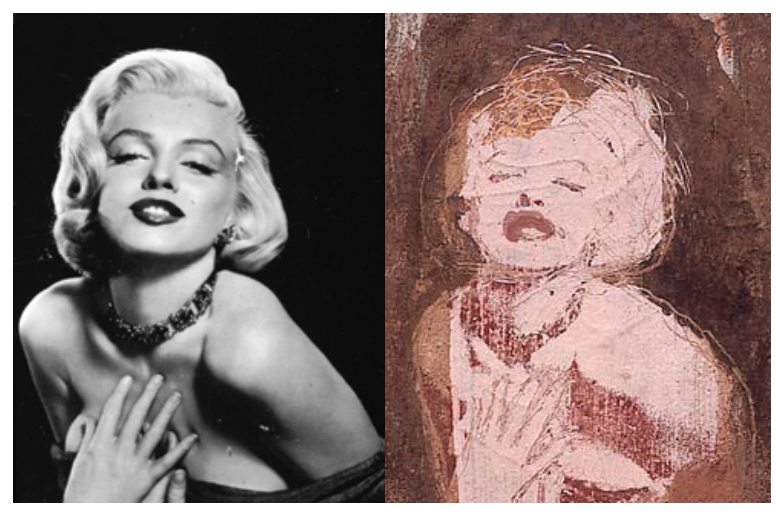

Figure 5: Two representations of Marilyn (latter 1996)

\section{CONCLUSIONS}

In this article the meaning of making and its products (i.e. artefacts) have been regarded as an essential part of research made in the field of practise-based research. The works created during the practise-based research process can be conceived as answers to the posed research questions as well as artistic or designerly argumentation on the chosen topic. As an object made by an artist- or designer-researcher, the artefact can also be seen as a method for collecting and preserving information and understanding.

However, the artefacts created during these research processes do not seem to present knowledge relevant to a research context. On the contrary, artefacts present themselves as mute objects which do not reveal their stories until interpreted. The crucial task for each practise-based research project is, therefore, to give a voice to the artefact. This means that we have to interpret an artefact in a certain context. This action seems to break the muteness of the artefact and give it a voice so it can tell its story.

One of the key issues in an ongoing discussion in the field of practise-based research is the manner in which a dialogue between arts and design practices and research is brought about. When building up the interaction between these two fields, the chosen context for carrying out this task seems to have a crucial importance. In this article, I have proposed that a well-structured practise-based research can be a natural way for designer to know; to make research and to argue. In this way the research projects carried out in a practise-based context can also increase the significance of the research carried out in the field of design.

\section{ACKNOWLEDGMENTS}

I want to thank the UIAH research community at the School of design for inspiring and educational discussions, especially Tuuli Mattelmäki who introduced me to the key literature on the "designerly way of knowing". I am grateful to Sara Routarinne for helping me to structure this article.

\section{REFERENCES}

1. AHRB. Guide for the fellowships in the creative and performing arts scheme. The UK Arts and Humanities Research Board, London, UK, 2001.

2. Biggs, M. The role of the artefact in art and design research. International journal of design sciences and technology 10, 2 (2002), 19-24.

3. Biggs, M. Learning from experience: approaches to the experimental component of practise-based research. Forskning, reflection, utveckling. Rapport från ett seminarium i Sigtuna 2004.

Vikhagen.net/research/ForskningReflektion.pdf.

4. Braidotti, R. Nomadic subjects. Embodiment and sexual difference on contemporary feminist theory. Columbia University Press, New York, USA, 1994.

5. Cross, N. Designerly ways of knowing. Design studies 3, 4 (1982), 221-227.

6. Cross, N. Design research: a disciplined conversation. Design issues 15, 2 (1999), 5-10.

7. Cross, N. Designerly ways of knowing. Design discipline versus design science. Design issues 17, 3 (2001), 49-55.

8. Durlind, D. \& Friedman, K. \& Gutherson, P. Editorial: debating the practise-based $\mathrm{PhD}$. International journal of design sciences and technology 10, 2 (2002), 7-18.

9. Eskola, T. Water lilies and wings of steel: interpreting change in the photographic imaging of Aulanko park. University of Art and Design Helsinki UIAH, Helsinki, Finland, 1997.

10.Irigaray, L. Speculum de l'autre femme. Les Éditions de Minuit, Paris, France, 1974.

11.de Lauretis, T. Alice doesn't. Feminism, semiotics, cinema. Indiana Univesrity Press, Bloomington, USA, 1984.

12.de Lauretis, T. Feminist studies/critical studies: Issues, Terms and Contexts. In Teresa de Lauretis (ed.) Feminist studies/critical studies. Indiana University Press, Bloomington, USA, 1986, 1-19.

13.Malins, Julian \& Gray, Carole. Educating the practice-based researcher: developing new environments for collaborative and constructive learning. In D. Durling \& K. Friedman (eds.) Foundations for the future. Doctoral education in design. Staffordshire University Press, Staffordshire, UK, 2000, 405-415.

14.Mäkelä, M. Saveen piirtyviä muistoja. Subjektiivisen luomisprosessin ja sukupuolen representaatioita. Taideteollinen korkeakoulu, Helsinki, Finland, 2003.

15.Ryynänen, L. Arts, Research and Doctoral Studies in Finland. Academy of Finland, Helsinki, 1999.

16.Schön, D. The reflective practitioner: how professionals think in action. Arena, Hants, England, 1995 (1983).

17. Scrivener, S. Towards the operationalisation of design research as reflection in and on action and practise. In D. Durling \& K. Friedman (eds.) Foundations for the future. Doctoral education in design. Staffordshire University Press, Staffordshire, 2000, 405-415.

18.Scrivener, S. Characterising creative-production doctoral projects in art and design. International journal of design sciences and technology 10, 2 (2002a), 25-44.

19.Scrivener, S. The art object does not embody a form of knowledge. Proceedings of the research into practise conference. Selected papers vol 2, 2002b. www.herts.ac.uk/artdes1/reseasch/papers/

20.Scrivener, S. and Chapman, P. The practical implications of applying a theory of practise based research: a case study. Proceedings of the research into practise conference. Selected papers vol 3, 2004. www.herts.ac.uk/artdes1/reseasch/papers/wpades/vol3/ssful l.html

21. Simon, H. The sciences of the artificial. The MIT Press, London, England, 1996 (1969). 